\title{
Poetic Conception of Robert Frost
}

\section{Ch.Aruna}

Lecturer in English, Hindu College, Guntur arunach789@gmail.com
V.Beulah Rani

\author{
Lecturer in English, Hindu College, Guntur \\ beulah77v@gmail.com
}

\begin{abstract}
Robert Frost's life, like his poetry is filled with curious contradictions. He wrote poetry using traditional theories and practices of versification. Frost said there is striking analogy between the course of a true poem and that of a true love, each begins as an impulse, a disturbing excitement to which the individual surrenders himself. This kind of inspiration is no way related to what words worth had in mind when he referred to emotions recollected in tranquility.

The first kind of recognition which Frost suggests a part of poetic impulse may be seen by examining his stopping by woods on a snowy evening. Speaking about the relationship between the poem and the reader, Frost says the poem is twice blest once by the poet and then by the reader. Frost's poetry is the poetry that never pretends it is the poetry of conversation and playing style. It sums up the past and enlivens the present for happy and wise future. It transcends time and space. It is universal in its appeal. It is powerful enough to express both things and thoughts. It is symbolic it plays on modern technique of contrasts and suggestions. We talked and laughed, but for the most part listened which Robert Frost kept on and on and on.
\end{abstract}

Keywords: Beauty, Duty, Metaphor, Nature, Inspiration, Memories.

\section{INTRODUCTION}

Robert Lee Frost holds a unique and almost isolated portion in American letters. Though his career fully spans the modern period and though it is impossible to speak of him as anything other than a modern poet, it is difficult to place him in the main tradition of poetry.

Frost stands at the cross roads of $19^{\text {th }} \mathrm{C}$ tendencies and traditions as well as parallels to the works of his $20^{\text {th }} \mathrm{C}$ contemporaries. His work was initially published in England before it was published in America. He is highly regarded for his realistic depictions of rural life and his command of American colloquial speech. This four time Pulitzer prize winner in poetry, depicted realistic New England life through language and situations familiar to the common man. He was a special guest at President John.F.Kennedy's inauguration, Frost became a poetic force and the unofficial "Poet laureate" of the United States.

The greatest of all modern poets, T.S. Eliot and many other poets are profoundly influenced by the technique and themes of the imagist Robert Frost. Pound thanked him for 1breaking away from "stilted Pseudo- literary language" and daring to write in the Natural speech of new-England. His poetry is deceptively simple, He uses speech tones for his poetic style. Though his style is speech rhythm, it is elevated and inimitable. Frost further created the illusion of a new England Farmer-poet writing the poetry of opinion, the woods, since Frost stroke strove hard towards pastoral poetry of the woods that are lovely, dark deep and Frosty. He has come out of the restrictions of the contemporary poets in their quest for new ways to be new and teased them for their desperate attempts to follow same body.

He said, "Poetry, for example, was tried without punctuation. It was tried without capital letters. It was tried without any image but those to the eye. It was tried without phrase, epigram, coherence, logic and consistency. It was tried without ability, these many things was it tried without, and what had we left? Still something "-Frosts" introduction to king Jasper. These restrictions amused Frost.

Frost has said many times that there is a striking analogy between the course of a true poem and that of a true love, each begins as an impulse, a disturbing excitement to which the individual surrenders himself. "No one can really hold that the ecstasy should be static and stand still in one place. It begins in delight, it inclines to the impulse, it assumes direction with the first line laid down, it runs the course of lucky events and ends in a clarification of life "-Frosts" The Figure a poem Makes. 
This kind of inspiration is in no way related to what Words worth had in mind when he referred to "emotions recollected in tranquility". It is most closely related to the recognition scene, the poets fresh recognition creates an emotional crisis, he impells to find release from the crisis and the resolution of it is the poem.

The first kind of recognition which Frost suggests as a part of poetic impulse may be seen by examining his "stopping by woods". The poem is a dramatic lyric which breaks into the middle of are incident so that there is a drama in miniature, revealed with setting and lighting and actors. Frost never mystifies nature as Words worth. It is only a backdrop to his profound philosophical thoughts. $\mathrm{He}$ is more a poet of man than a nature he sees man as always cradled within nature.

William Words worth, the prophet of nature took pleasure in turning from the present to find an emotional excitement and inspiration in happy memories of the past.

Paradoxically Words worth goes to the vernal woods to escape from the unpleasantness of the present. Frosts method is diametrically opposed. He takes pleasure in ignoring the ultimate reality takes pleasure even in turning his back on the past, until a momentary experience is illuminated with richen value by that his past experience accidentally brings to the present.

He says, "For me the initial delight is in the surprise of remembering something I did not know I knew, I am in a place, in a situation, as if I had materialized from a cloud or risen out of the ground. There is a glad recognition of the long lost and the rest follows- The figure a poem makes.

Frost does not imply that the poem writes itself. The poet must establish a careful balance between the present experience and the remembered experience. This equilibrium is truly a large part of artistry. To attain this equilibrium "you adjust yourself to the motion of the thing itself". The projection of the poem arises out of the poets' pleasure in discovering words, images, metaphors, phrases, native to the grain of emotion, thought and situation.

Like Emerson (his essay theory of poetry) Frost also say that meaning in a poem is a means to end and the end is delight. Beauty is its own excuse for being, that the delight is the goal. On a higher plane, there is a pleasure which arises from a deeper understanding let the poem start and finish even so playfully, it will touch and illuminate experience. For Frost poetry highlights certain permanent truth and enduring qualities in human nature.

Speaking about the relationship between the poem and the reader, Frost says the poem is twice blest once by the poet and then by the reader. The readers understanding or perceptivity of a poem is an important thing. His comprehension guarantees its "Merit and meaning". It must be able to establish a basic correspondence between writer and reader. Eliots terrible poem, 'The waste land', falls short of common comprehension, but Frosts' poems do not. They are easily grasped.

In his essay "The constant symbol", Frost defines a poem as a metaphor. "Poetry is simply made of metaphor" He gives a dramatic situation or twist to most of his poems by developing them through speakers and characters. Best example is "stopping by the woods on a snowy evening" It reads like a drama. The characters are the speaker and his horse. There is situation, climax and resolution and also symbols. He hates to see poets use their medium as a vehicle for shrieking frustration and disgust. Grievance he would willingly restrict to prose. His aim is to delight, and this delight leads to wisdom. In his own words- (from the figure a poem makes) a poem begins in delight and ends in a clarification of life... in a momentary stay against confusion". One takes delight in the casual way his poems begins and is surprised at the turn they take and had up to a clarification of life.

Life appears- symbols, figures, conflicts, journeys etc from the poems we have studied.

The figure - begin in delight and ends in a clarification of life frost has reverence for the living process, in itself a power of creative resistance to the flux of matter.

Frost expresses his ideas and feelings in a simple and graphic language. He introduces speaking voices in his poems. Most of the poems are simple truths are revealed through technical subtleties and symbols. Written in the colloquial or speaking manner. These characters put forth their views independently. To expedite the effect of ordinary speech, the poet takes resort to dots, dashes, parentheses and Quick transitions of thought his poem begin in a casual way, very often the poet employs the drama of the speaking voice as we seen in 'Home Burial' In order to sound realistic and natural Frost does not care for syntax and structure. Frost enlivens his variation by using the method 
of direct speech. By such a method the poet can effectively convey what he wants to. This is what he means by clarification. We have a good deal of drama in poems in Mending wall. The poet exploits the use of speech. In stopping by woods, we have not only the nature - description of the first rank, but also the philosophical undertones and the symbolic wrappings especially in the last stanza.

\section{The woods are lovely dark and deep.}

\section{But I have promises to keep,}

And miles to go before I sleep,

And miles to go before I sleep.

Earth is the right place for love, I don't know where it's likely to go better- Birches.

Sometimes Frosts' diction becomes aphoristic and proverbial such as in-

'good fences make good neighbors - Mending wall.

Frost is above all a nature poet again he is not a nature mystic like Words worth. Man has need for nature, though he should never make the mistake of crossing the wall into her pasture. The woods are lovely, dark and deep against the snowfall, a place to linen and forget duty; but to linger only and not to stay. Frost believes that nature is different towards man, Man is to survive by being courageous and fearless in the face of natural barriers.

There is much in nature against us, But we forget

including human nature, in peace and war,

And it must be a little more in favour of man (our hold on a planet).

To sustain such injuries as nature inflicts, "It's well to have all kinds of feelings, for it's all kinds of a world. And frost expresses all kinds of his feelings towards the natural world. Words worth would never have (even in his worst dream) written like this.

He never sees in the natural world the pervading spirit which Words worth saw. What is high seriousness is Words worth is humor in Frost.

In Frost's nature- poetry we find the picture of lonely man, the solitary protagonists in Home burial, stopping by woods, Birches etc.

Frost is above all the poet of humanity, he picturises the actual life lived by the people in new England and new Hampshire. He has written on many subjects, but his external subject is humanity. Others have written about people, but Frost's poem are the people. They converse and fell their stories with the freedom of common speech. His treatment of man is significant. He gives humanity a better place than nature in his heart and poetry.

His treatment of mankind is based on realism. He does not idealize or glorify his men and women. No American written knows his subjects, people and place, so thoroughly as he does. Frost once said "There are two kinds of realism, the one who shows potato with its dust and the other who is satisfied to show a potato brushed clean. I am inclined to be the second kind.

Frost is mainly interested in the contradictions which his characters show in their makeup. He believes that life itself is a bundle of contradictions. He lets them express their views freely and frankly through the medium of dialogue in the poems. We may or may not agree with them and their stand, this is the liberal understanding of frost for instance. Mending wall is both a plea for doing away with the wall "Something there is that does not love of wall" and a plea for its retention- "Good fences make good neighbours". Though the neighbours attitude is conservative rather than progressive, the poet says due respect to his traditional standard.

In birches he shows a village boy and his pass time climbing the birches, not only in doing so he becomes universal, but he also gives his approval to what the boy does. So was once myself a swinger of birches. And So I dream of going back to be.

Frosts people do not suffer from a sense of ignobility and lack of courage. They strive towards their goal without a shoulder, despite their censatory existence. They are in brief brave and heroic in advise situation. 
They try again "to set the wall between us once again" - Mending wall

They quarrel "Oh, you think the talk is all, I must go-

Some where out of this house, how can I make you”

\section{- Home burial.}

They dream of "Magnified apples"-Apple picking

They are indecisive about the Road not taken and some times

They are hesitant "And that has made all the difference". - The Road not taken

They fancy "Some say the world will end in fire

Some say in ice"- Fire and ice

The learn even from a hose- the time sense,

"He (horse) gives his harness bells a shake

To ask if there is some mistake"- stopping by woods

They converse with a brook. It reminds them about their origin

"It is Tran what in water we were from

Long, long before we were from any creature"

-West running brook.

Thus, Frost men represent certain universal qualities. They are brave and heroic. Perhaps that is life a clarification of it.

\section{Conclusion}

Finally, Frost's poetry is the poetry that never pretends. It is the poerty of conversation and plain style. It seems up the past and enlivens the present for a happy and wise future. It transcends time and space. It is universal in its appeal. It is powerful enough to express both things and thoughts. It is symbolic it plays on the modern technique of contrasts and suggestions.

"We talked and laughed, but for the most part listened while Robert Frost kept on and on and on". Holding us with shrewd turns and racy quips like a piece of ice on hot coals his poetry melts on to its his ultimate goal- beginning gin delight and ends in wisdom.

Frosts poetry is subjective. His poems were used by President Kennedy for his election campaign. He participated in the American Presidents inauguration programme. He visited Russia in 1961 as a cultural ambassador. And it was then he read his poem "Mending wall" - The poet's reprimand to the Russians. He died in Boston in 1963. President Kennedy mourn him in the following words.

"His death impoverished all of US but he has bequeathed his nation a body of imperishable verse from which Americans will forever drive joy and understanding. He has promises to keep and miles to go and now he sleeps".

\section{REFERENCES}

[1] Critical Insights - Robert Frost.

[2] Robert Frost in Context - Mark Richardson.

[3] The Poetry of Robert Frost The collected poems, Complete \& Unabridged.

[4] The Road not Taken - David Orr.

[5] Robert Frost's poetry of Rural life - George Monteiro.

[6] Of a winter evening - Robert Frost.

[7] A witness Tree - Robert Frost.

[8] Collected poems, prose \& plays (Literary of America-1995)

[9] Monterio, George, Robert Frost \& the New England renaissance. Lexington. Ky: University press of Kentucky.

[10] Robert Frost's "Mending wall". A marriage of poetic form and content. 


\section{AUTHORS' BIOGRAPHY}

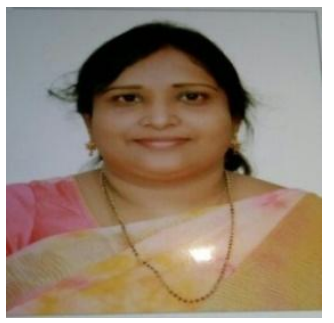

Velpula Beulah Rani, have been in service as a Lecturer in English in this August body since 2000. I have enriched my teaching and language skills by participating in various National and International seminars and workshops. Eight of my research articles have been published in different souvenirs. Three of my research articles have been published in international souvenirs.

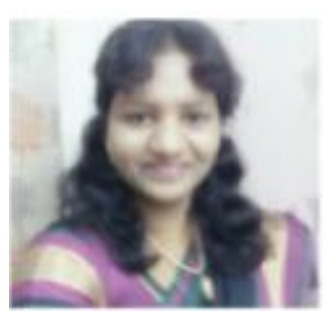

Chilka Aruna, as a Lecturer in English have been rendering services to the prestigious institution Hindu College, Guntur since 2000. In 2008, I became the Head of the Department. Coming to my personal profile, I have been awarded the A.P.STATE BEST TEACHER AWARD in 2015. Twelve of my research articles have been published in different souvenirs. I feel proud to say that I have been awarded the GURU BRAHMA NATIONAL AWARD-2016 by the MOTHER THERESA SOCIAL WELFARE ORG. (Regd.No:649/2010) in the year 2016. I have participated in various National \& International seminars and workshops. Thus I have enriched my language skills as well as teaching skills. Once again I feel proud to say that I have exchanged my views regarding literature and language with popular literary figures and experts in communication skills. 